\title{
Elemental Contamination in Various Species of Birds from Select States in India
}

\author{
Kirubhanandhini Venkatasalam $^{1^{*}}$, Muralidharan Subramanian ${ }^{2}$, Ganesan Kittusamy $^{3}$ and \\ Shashikant Shivaji Jadhav ${ }^{4}$ \\ ${ }^{1,2 \& 3}$ Salim Ali Centre for Ornithology and Natural History, Coimbatore, Tamil Nadu, India \\ ${ }^{4}$ Jivdhaya Charitable Trust, Ahmedabad, Gujarat, India \\ *Corresponding Author \\ E-Mail: knlifescience01@gmail.com, ecot_mur@yahoo.com
}

\begin{abstract}
With the aim, to assess the magnitude of elemental contamination in birds in select states in India, samples of bird tissues were analyzed for copper $(\mathrm{Cu})$, lead $(\mathrm{Pb})$, cadmium (Cd) and chromium (Cr), with Atomic Absorption Spectrophotometer. Elements were detected in all the tissues and significant differences were noted in their concentrations among the species and tissues $(P>0.05)$. Out of the 10 species analyzed, Bar - headed Goose and Red - wattled Lapwing accumulated the highest and Eurasian Collared - dove the lowest concentration of all the elements analyzed. Of all the tissues, kidney accumulated the maximum concentration of $\mathbf{P b}$ $(11.77 \mu \mathrm{g} / \mathrm{g}), \mathrm{Cd}(17.06 \mu \mathrm{g} / \mathrm{g})$ and $\mathrm{Cr}(16.08 \mu \mathrm{g} / \mathrm{g})$. Apart from the organs studied, gut content also had notable levels of elements, which indicated the present contamination status of the environment. Nonetheless, the levels of most of the elements measured in the present study were considered nontoxic.

Keywords: Elements, Birds, Tissues, Bio-Indicators, Toxic, Contamination
\end{abstract}

\section{INTRODUCTION}

Increasing environmental contamination by elements has been a major concern in recent years in all industrialized nations in South Asia Bhuyan\& Islam [7], including India. While elements are deposited on soils through geological activity, aerial deposition, flooding or anthropogenic sources, primary receptors such as microbes, plants and macro invertebrates pick them up from soil and other abiotic components, and transfer those elements to higher-level organisms [8]. In this process essential elements also can turn toxic to birds, humans and all other organisms, if exposure levels are above permissible limits [17].

Birds are one of the major victims of environmental contamination as they occupy a wide range of tropic levels in different food chains. Among wildlife, birds have been used as effective bio-indicators for a number of environmental contaminants including elements [22]. Thus, monitoring elements in birds from a delimited area periodically could be useful to assess not only the health of the species, but also the fluctuations in contamination levels in the environment where they live [30].

In India studies on elemental contamination in birds are limited. However, there is some information available on sixteen species of aquatic birds in Koeladeo National Park, Bharatpur Muralidharan (24), House Sparrow in Jaipur Bakre and Sharma [2] and Indian White-backed Vulture Rajamani and Subramanian [27] in lead, cadmium, zinc and copper. Thus with the aim to generate more information on elemental contamination in birds in India, a study was launched, and information on 10 species of birds is presented in this article.

\section{METHODS AND MATERIALS}

\section{A. Sample Collection}

Samples of birds were collected on opportunistic basis from states, namely Tamil Nadu, Gujarat, Kerala and Assam between 2010 and 2014. Collected samples were transported to SACON Ecotoxicology laboratory over ice. Circumstantial evidences at the collection sites were gathered, and morphometric measurements were recorded at the time of conducting postmortem. Muscle, liver, kidney and gut content were collected and packed without any external contamination, stored at $-20^{\circ} \mathrm{C}$ until chemical analysis.

\section{B. Sample Digestion and Analysis}

About 1 to $1.5 \mathrm{~g}$ (wet weight - ww) of samples were weighed with a reproducibility of $0.02 \mathrm{~g}$ in Mettler AE 240 balance and digested in Microwave Digestion System (Milestone, MLS 1200) using $10 \mathrm{~mL}$ Nitric Acid (69 \% GRMerck) for $10 \mathrm{~min}, 1 \mathrm{~mL}$ Perchloric Acid (70\% GRMerck) for $5 \mathrm{~min}$ and $5 \mathrm{~mL}$ Hydrogen Peroxide (30\% GRMerck) for $10 \mathrm{~min}$ at $250 \mathrm{~W}$ magnetron power settings. The digested solutions were filtered through Whatman No. 1 filter paper, made up to $25 \mathrm{~mL}$ with double distilled water and stored in polythene vials in refrigerator, and subsequently analyzed for metals, namely copper $(\mathrm{Cu})$, lead $(\mathrm{Pb})$, cadmium $(\mathrm{Cd})$ and chromium $(\mathrm{Cr})$ using a double beam Atomic Absorption Spectrophotometer (Perkin Elmer, AA 800). Standards for all the referred metals manufactured by SISCO Research Laboratories Pvt. Ltd., India were used for calibration. While the detection limit for copper was $2.0 \mathrm{ppb}$, it was $1.0,3.0$ and $2.0 \mathrm{ppb}$ for cadmium, lead and chromium respectively. The 
quantification limits of metals were three times the detection limit. Recovery rates for $\mathrm{Cu}, \mathrm{Pb}, \mathrm{Cd}$, and $\mathrm{Cr}$ were $86,88,85$, and $90 \%$, respectively. The results were not corrected for percent recovery, and expressed in $\mu \mathrm{g} / \mathrm{g} \pm \mathrm{SE}$ (ww). In order to facilitate comparison with published information which are on dry weight basis, a conversion factor of three was used [10], wherever required.

\section{Statistical Analysis}

The data did not meet the assumption of normal distribution when checked using Shapiro-Wilk test $(\mathrm{p}<0.05)$. Hence, Kruskal-Wallis, a non-parametric test was performed to check the difference in elemental contamination among species and tissues. $P$ values less than 0.05 were considered statistically significant. Statistical analyses were performed using SPSS software, Ver. 2.6.

\section{RESULTS AND DISCUSSION}

Totally 93 individuals comprising 10 species of birds were collected dead from four states in India (Table I). Concentrations of metals, namely $\mathrm{Cu}, \mathrm{Pb}, \mathrm{Cd}$ and $\mathrm{Cr}$ were compiled to look at the variations in contamination level among the species and tissues. Accumulation of elements differed among the species studied (Table II).

TABLE I SPECIES OF BIRDS COLLECTED DEAD FROM DIFFERENT STATES IN INDIA FOR THE STUDY BETWEEN 2010 AND 2014

\begin{tabular}{|c|l|c|c|c|}
\hline S. No. & \multicolumn{1}{|c|}{ Common name } & Scientific name & No. of individuals & Current population trend (IUCN, 2018) \\
\hline 1 & Bar-headed Goose & Anser indicus & 03 & Decreasing \\
\hline 2. & Red-naped Ibis & Pseudibis papillosa & 06 & Decreasing \\
\hline 3 & Rock Dove & Columba livia & 24 & Decreasing \\
\hline 4 & Cattle Egret & Bubulcus ibis & 21 & Increasing \\
\hline 5 & House Crow & Corvus splendens & 19 & Stable \\
\hline 6 & Indian Peafowl & Pavo cristatus & 06 & Stable \\
\hline 7 & Indian Pond - heron & Ardeola grayii & 03 & Unknown \\
\hline 8 & Red - wattled Lapwing & Vanellus indicus & 04 & Increasing \\
\hline 9 & Eurasian Collared - dove & Streptopeli adecaocto & 03 & Increasing \\
\hline 10 & Rose-ringed Parakeet & Psittacula krameri & 04 & 93 \\
\hline
\end{tabular}

On an average, Bar-headed Goose had the highest concentration of copper $(80.08 \pm 15.37 \mu \mathrm{g} / \mathrm{g} \mathrm{ww})$ in gut content followed by liver $(73.58 \pm 5.47 \mu \mathrm{g} / \mathrm{g}$ ww) while Eurasian Collared - dove accumulated the lowest $(2.95 \pm$ $0.57 \mu \mathrm{g} / \mathrm{g} \mathrm{ww})$ in kidney. Significant variations were observed in the level of copper among the species of birds (Kruskal-Wallis test, $n=159 ; H=9.65 ; \mathrm{P}<0.05$ ) studied.

Waterfowl are affected by copper intoxication through ingestion of water contaminated by antifouling paints [14]. Other sources of copper include copper wire, pennies or any copper coated objects small enough to be ingested by birds [4]. But, birds appear to tolerate higher levels of copper than many mammals [28]. There have been reports on Mute Swans tolerating liver copper residues up to $1000 \mu \mathrm{g} / \mathrm{g} \mathrm{ww}$ [13]. Jayakumar and Muralidharan [18] reported copper levels in a few aquatic birds in the range of $1.50-9.77 \mu \mathrm{g} / \mathrm{g}$ ww in kidney tissues which showed no sign of toxicity. The study conducted in Rock Dove from Bangladesh documented $3.44 \mu \mathrm{g} / \mathrm{g}$ ww in muscle and $8.72 \mu \mathrm{g} / \mathrm{g} \mathrm{ww}$ in kidney of [5]. Hence, the concentrations of copper recorded in all the 10 species of birds studied were less than levels capable of inducing any toxic effects. Lead being a widespread environmental contaminant, has a history of causing mortality of millions of ducks across Europe and North America [31, 37]. However, in India there are no such reports. The maximum concentration of lead was found in gut content of Red - wattled Lapwing $(55.85 \pm 13.09 \mu \mathrm{g} / \mathrm{g}$ ww) followed by gut content of Bar-headed Goose (31.92 \pm $6.70 \mu \mathrm{g} / \mathrm{g} \mathrm{ww})$. The minimum concentration was in Cattle Egret $(0.29 \pm 0.03 \mu \mathrm{g} / \mathrm{g} \mathrm{ww})$ in its muscle (Table II).

The levels were significantly different among the species $(\mathrm{P}<0.05)$ studied. Levels of lead recorded in the present study were relatively lower than the levels recorded in muscle tissues of Canada Geese $(60.4 \mu \mathrm{g} / \mathrm{g}$ ww) [34]. Kim and Koo [19] reported lead levels exceeding the threshold levels of approximately $29.4 \mu \mathrm{g} / \mathrm{g}$ ww in liver of Rednecked Stints and called it as indicative of chronic lead exposure. Concentrations more than 6 and $15 \mu \mathrm{g} / \mathrm{g}$ in kidney of Kestral was reported to be associated with impaired growth and survival respectively [29].

Lead affects birds both indirectly by reducing food supplies Eeva and Lehikoinen[11] and directly by affecting reproduction, behavior, and hematopoietic and nervous systems [16, 35]. Although signs of lead poisoning in birds vary among species Beyer et al. [6], the same could not be ascertained as the birds included in the present study were collected only after they were dead. However, the levels of lead in Red- wattled Lapwing $(55.85 \pm 13.09 \mu \mathrm{g} / \mathrm{g} \mathrm{ww})$ and Bar - headed Goose $(31.92 \pm 6.70 \mu \mathrm{g} / \mathrm{g} \mathrm{ww})$ in the present study can be considered alarming when compared to earlier studies [19, 29]. 
Cadmium is characterized by its highest accumulation factor in living organisms [20]. At lower concentrations, Cd may lead to development of behavioral and sub lethal effects as compared to $\mathrm{Pb}$ and $\mathrm{Hg}$ [16]. Cadmium concentration was the highest in Indian Pond Heron $(27.94 \pm 10.10 \mu \mathrm{g} / \mathrm{g} \mathrm{ww})$ followed by Indian Peafowl $(22.03 \pm 21.53 \mu \mathrm{g} / \mathrm{g}$ ww) in kidney. Out of the ten species of birds studied, the Eurasian Collared Dove had the lowest level of Cd in muscle $(0.34 \pm$ $0.24 \mu \mathrm{g} / \mathrm{g} \mathrm{ww})$.

Muralidharan [24] in his study on metal contamination in sixteen species of aquatic birds had recorded $2.12 \mu \mathrm{g} / \mathrm{g}$ of $\mathrm{Cd}$ in the kidney of Indian Pond Heron. Kidney damages have been reported in wild colonies of pelagic sea birds having $\mathrm{Cd}$ level of $60-480 \mu \mathrm{g} / \mathrm{g}$ in their kidneys [38]. Cadmium in breast muscles of mallards in Europe was $0.082 \mu \mathrm{g} / \mathrm{g}$ ww [32]. Cadmium levels in liver of Canada Geese, although were higher than other tissues at over 0.20 $\mu \mathrm{g} / \mathrm{g}$ in Mill Creek and over $0.30 \mu \mathrm{g} / \mathrm{g}$ at Skeetkill Marsh were not anywhere close to the avian threshold (41.02 $\mu \mathrm{g} / \mathrm{g}$ ww) for $\mathrm{Cd}$ poisoning [15]. Thus, the present study shows that the concentrations of $\mathrm{Cd}$ among the 10 species of birds were less than levels capable of causing any toxicity.

Chromium being a trace element is an essentialmicronutrient in animal diet [26]. Interestingly both maximum and minimum levels of chromium were in Rock Dove. While kidney had the maximum (31.92 $\pm 16.64 \mu \mathrm{g} / \mathrm{g} \mathrm{ww})$, muscle had the minimum levels $(3.49 \pm 1.08 \mu \mathrm{g} / \mathrm{g}$ ww) (table 2). While Begum \& Sehrin [5] reported 1.85 and 0.91 $\mu \mathrm{g} / \mathrm{g}$ ww of $\mathrm{Cr}$ in kidney and muscle tissues of Blue Rock Pigeon respectively in Bangladesh, Torreset al., [33] reported $3.37 \mu \mathrm{g} / \mathrm{g}$ ww of $\mathrm{Cr}$ in muscle tissues of Blue Rock Pigeon in Spain, and these levels were similar to levels recorded in the present study. Sublethal effects of $\mathrm{Cr}$ in birds include growth retardation, anemia and testicular damage, and it is considered to be life threatening to the organism [36].

Since Blue Rock Pigeons are also consumed by man we suspect these conditions to adversely affect and create health risk in those end users [1, 5, 23]. The study recommends monitoring the levels of elemental contaminants including $\mathrm{Cr}$ in tissues of Blue Rock Pigeon. United States Fish and Wildlife Service [36] suggested that Cr levels in kidney tissues in excess of $40 \mu \mathrm{g} / \mathrm{g}$ ww should be considered as an evidence of $\mathrm{Cr}$ contamination. When compared to published information, levels recorded in the present study were found to be higher in all the species. But apparently these levels did not show any toxic effects.

TABLE II LEVELS OF ELEMENTS ( $\mu \mathrm{G} / \mathrm{G}$ MEAN \pm SE) IN DIFFERENT TISSUE OF BIRDS IN SELECT STATES IN INDIA

\begin{tabular}{|c|c|c|c|c|c|}
\hline Bird species & Organ & Copper & Lead & Cadmium & Chromium \\
\hline \multirow{4}{*}{$\begin{array}{l}\text { Bar-headed Goose } \\
(\mathrm{n}=03)\end{array}$} & Muscle & $41.61 \pm 11.72$ & $13.23 \pm 3.95$ & $8.75 \pm 3.24$ & $15.39 \pm 2.86$ \\
\hline & Liver & $73.58 \pm 5.47$ & $5.74 \pm 2.50$ & $5.97 \pm 0.87$ & $6.44 \pm 0.77$ \\
\hline & Kidney & $70.57 \pm 15.74$ & $7.30 \pm 1.10$ & $13.22 \pm 1.63$ & $8.15 \pm 1.35$ \\
\hline & Gut content & $80.08 \pm 15.37$ & $31.92 \pm 6.70$ & $4.22 \pm 0.76$ & $9.45 \pm 0.92$ \\
\hline \multirow{4}{*}{$\begin{array}{l}\text { Red-napped Ibis } \\
(\mathrm{n}=06)\end{array}$} & Muscle & $27.31 \pm 4.50$ & $9.71 \pm 3.59$ & $11.55 \pm 2.97$ & $5.91 \pm 1.62$ \\
\hline & Liver & $25.90 \pm 6.81$ & $16.98 \pm 3.89$ & $21.55 \pm 3.30$ & $7.29 \pm 0.63$ \\
\hline & Kidney & $6.28 \pm 1.93$ & $21.53 \pm 4.13$ & $25.49 \pm 2.80$ & $8.35 \pm 0.60$ \\
\hline & Gut content & $25.69 \pm 5.43$ & $17.11 \pm 3.56$ & $15.29 \pm 4.31$ & $10.59 \pm 2.35$ \\
\hline \multirow{4}{*}{$\begin{array}{l}\text { Rock Dove } \\
(\mathrm{n}=24)\end{array}$} & Muscle & $42.54 \pm 4.48$ & $3.48 \pm 0.58$ & $1.89 \pm 1.06$ & $3.49 \pm 1.08$ \\
\hline & Liver & $38.75 \pm 3.80$ & $6.45 \pm 0.82$ & $8.59 \pm 1.53$ & $8.19 \pm 3.60$ \\
\hline & Kidney & $17.72 \pm 02.88$ & $14.48 \pm 8.56$ & $13.19 \pm 3.09$ & $31.92 \pm 16.64$ \\
\hline & Gut content & $25.91 \pm 4.50$ & $13.73 \pm 3.29$ & $8.32 \pm 1.84$ & $7.49 \pm 1.08$ \\
\hline \multirow{4}{*}{$\begin{array}{l}\text { Cattle Egret } \\
(n=21)\end{array}$} & Muscle & $18.50 \pm 2.60$ & $0.29 \pm 0.03$ & $2.03 \pm 21.54$ & $10.83 \pm 2.96$ \\
\hline & Liver & $27.93 \pm 4.30$ & $4.92 \pm 1.43$ & $10.90 \pm 3.13$ & $15.85 \pm 4.65$ \\
\hline & Kidney & $18.56 \pm 3.21$ & $12.87 \pm 0.78$ & $21.93 \pm 2.71$ & $18.10 \pm 6.71$ \\
\hline & Gut content & $27.83 \pm 7.80$ & $29.92 \pm 6.70$ & $4.22 \pm 0.76$ & $16.10 \pm 3.57$ \\
\hline \multirow{4}{*}{$\begin{array}{l}\text { House Crow } \\
(n=19)\end{array}$} & Muscle & $42.28 \pm 11.52$ & $4.33 \pm 0.45$ & $5.544 \pm 3.56$ & $10.83 \pm 2.96$ \\
\hline & Liver & $45.03 \pm 10.64$ & $8.53 \pm 1.12$ & $8.78 \pm 1.87$ & $15.85 \pm 4.65$ \\
\hline & Kidney & $38.96 \pm 23.96$ & $9.20 \pm 1.26$ & $10.52 \pm 5.25$ & $18.10 \pm 6.71$ \\
\hline & Gut content & $13.94 \pm 2.09$ & $5.57 \pm 0.93$ & $2.59 \pm 0.64$ & $4.60 \pm 2.05$ \\
\hline \multirow{4}{*}{$\begin{array}{l}\text { Indian Peafowl } \\
(\mathrm{n}=06)\end{array}$} & Muscle & $10.13 \pm 1.53$ & $3.05 \pm 0.51$ & $4.12 \pm 1.33$ & $10.13 \pm 1.53$ \\
\hline & Liver & $54.34 \pm 24.29$ & $8.43 \pm 4.05$ & $8.16 \pm 3.53$ & $9.56 \pm 0.98$ \\
\hline & Kidney & $9.55 \pm 6.92$ & $12.09 \pm 0.03$ & $22.03 \pm 21.53$ & $10.48 \pm 3.09$ \\
\hline & Gut content & $15.48 \pm 10.58$ & $1.75 \pm 1.39$ & $1.51 \pm 0.60$ & $15.51 \pm 2.22$ \\
\hline
\end{tabular}




\begin{tabular}{|l|l|c|c|c|c|}
\hline \multirow{4}{*}{$\begin{array}{l}\text { Indian Pond-heron } \\
(\mathrm{n}=03)\end{array}$} & Muscle & $13.23 \pm 3.95$ & $5.04 \pm 2.34$ & $4.12 \pm 1.33$ & $10.13 \pm 1.53$ \\
\cline { 2 - 6 } & Liver & $49.31 \pm 20.08$ & $8.45 \pm 6.6$ & $16.26 \pm 7.18$ & $14.51 \pm 3.64$ \\
\cline { 2 - 6 } & Kidney & $46.96 \pm 2.22$ & $10.29 \pm 8.66$ & $27.94 \pm 10.10$ & $27.25 \pm 9.18$ \\
\cline { 2 - 6 } & Gut content & $28.50 \pm 6.03$ & $16.98 \pm 1.57$ & $6.55 \pm 3.22$ & $16.69 \pm 4.64$ \\
\hline \multirow{4}{*}{$\begin{array}{l}\text { Red -wattled Lapwing } \\
(\mathrm{n}=04)\end{array}$} & Muscle & $13.33 \pm 5.46$ & $6.66 \pm 3.59$ & $6.53 \pm 3.79$ & $5.78 \pm 1.74$ \\
\cline { 2 - 6 } & Liver & $25.96 \pm 11.67$ & $11.29 \pm 4.24$ & $12.06 \pm 4.94$ & $3.69 \pm 1.29$ \\
\cline { 2 - 6 } & Kidney & $19.00 \pm 5.19$ & $16.73 \pm 5.56$ & $21.30 \pm 7.29$ & $15.15 \pm 3.84$ \\
\cline { 2 - 6 } & Gut content & $6.65 \pm 6.07$ & $55.85 \pm 13.09$ & $0.93 \pm 0.24$ & $7.74 \pm 0.53$ \\
\hline \multirow{4}{*}{$\begin{array}{l}\text { Eurasian Collared-dove } \\
(\mathrm{n}=03)\end{array}$} & Muscle & $2.95 \pm 0.57$ & $13.07 \pm 1.86$ & $0.34 \pm 0.24$ & $2.85 \pm 0.83$ \\
\cline { 2 - 6 } & Liver & $6.88 \pm 2.49$ & $9.78 \pm 3.70$ & $7.15 \pm 6.55$ & $5.29 \pm 1.54$ \\
\cline { 2 - 6 } & Kidney & $15.27 \pm 1.03$ & $12.87 \pm 0.78$ & $21.93 \pm 2.71$ & $13.20 \pm 4.21$ \\
\cline { 2 - 6 } & Gut content & $12.29 \pm 1.05$ & $29.76 \pm 8.34$ & $1.86 \pm 0.46$ & $13.72 \pm 2.65$ \\
\hline \multirow{4}{*}{$\begin{array}{l}\text { Rose-ringed Parakeet } \\
(\mathrm{n}=04)\end{array}$} & Muscle & $11.29 \pm 2.84$ & $13.07 \pm 1.86$ & $1.34 \pm 0.24$ & $7.85 \pm 0.83$ \\
\cline { 2 - 6 } & Liver & $19.68 \pm 2.74$ & $27.74 \pm 4.64$ & $5.93 \pm 1.54$ & $17.69 \pm 4.82$ \\
\cline { 2 - 6 } & Kidney & $14.42 \pm 1.67$ & $23.52 \pm 3.69$ & $2.71 \pm 0.86$ & $13.08 \pm 2.07$ \\
\cline { 2 - 6 } & Gut content & $20.16 \pm 5.16$ & $7.50 \pm 0.29$ & $10.68 \pm 1.53$ & $11.53 \pm 0.30$ \\
\hline
\end{tabular}

The variation in levels of elemental contaminants among tissues irrespective of species was also compiled to understand the accumulation potential of the organs. Organs play vital role in accumulating metals. Particularly, liver and kidney are involved in detoxification mechanisms [3]. Even though number of individuals in each species was less because of opportunistic sampling, we tried to find out the tissue which accumulated the maximum concentrations of elements (Fig.1). One way ANOVA Post hoc test was performed to compare the levels of elemental contamination in the tissues.

Of all the tissues, muscle accumulated the minimum concentration of all the elements $(\mathrm{Cu}-2.17 \pm 1.58 \mu \mathrm{g} / \mathrm{g} \mathrm{ww}$; $\mathrm{Pb}-6.11 \pm 2.36 \mu \mathrm{g} / \mathrm{g} \mathrm{ww}$; Cd-3.91 $\pm 2.47 \mu \mathrm{g} / \mathrm{g}$ ww and Cr$1.11 \pm 0.46 \mu \mathrm{g} / \mathrm{g}$ ww). Rajamani and Subramanian [27] reported of lead $1.72 \mu \mathrm{g} / \mathrm{g}$ in muscle in Indian White backed Vulture to be not toxic.

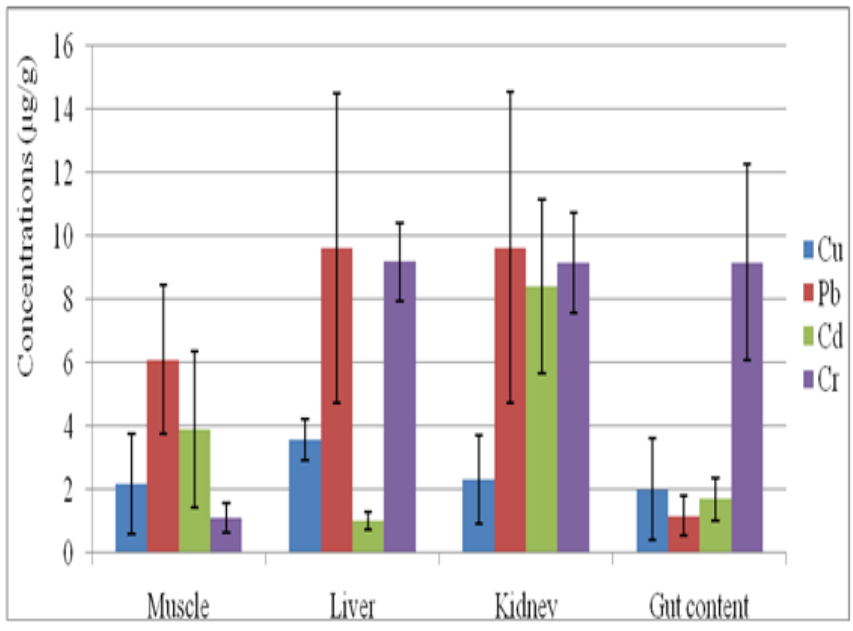

Fig. 1 Variation in elemental contamination among organs in birds collected from select states in India $(\mu \mathrm{g} / \mathrm{g}$ Mean $\pm \mathrm{SE})$
Liver accumulated only copper in higher concentrations $(3.56 \pm 0.64 \mu \mathrm{g} / \mathrm{g}$ ww among other tissues. Kidney accumulated higher concentrations of $\mathrm{Pb}, \mathrm{Cd}$ and $\mathrm{Cr}(9.62 \pm$ $4.89 \mu \mathrm{g} / \mathrm{g} \mathrm{ww} ; 1.01 \pm 0.27 \mu \mathrm{g} / \mathrm{g} \mathrm{ww} ; 9.19 \pm 1.24 \mu \mathrm{g} / \mathrm{g} \mathrm{ww})$ respectively. Similar levels Cd $(1.10 \mu \mathrm{g} / \mathrm{g}$ ww $)$ in kidney were reported in Greater White-fronted Goose (Anseralifrons) [39]. Apart from the organs studied, gut content also had notable levels of heavy metals, which indicates the present status of elemental contamination of the environment.

\section{CONCLUSION}

Further, in order to evaluate any instance of element poisoning, normal levels of them for the species concerned must be and the known abnormal levels, which tend to produce either harm or no apparent harmful effects, must be recognized which is a conspicuous need in Indian context. Aquatic birds are particularly vulnerable to contaminants, including elements [25]. Kidney and liver are the major organs which respond to the insult of elemental contamination owing to their physiological role $[18,21]$. Similarly the data generated in this study also show the liver and kidney tissues of birds to be good indicators of elemental contamination in the environment.

\section{ACKNOWLEDGEMENT}

We thank the Ministry of Environment, Forest and Climate Change, Government of India for financial support, forest departments of Gujarat, Assam, Kerala and Tamil Nadu for granting permits to collect bird samples, MrKartikShastri and Jivdaya Charitable Trust, Ahmedabad for their help in sample collection. We express our sincere gratitude to the Director, SACON for the support, Dr. S. Jayakumar, Assistant Professor, AVC College, for his help in statistical analysis and Dr. R. Jayakumar, Assistant Professor, GITAM University for his help in drafting this manuscript and Mr. T. Manikandan for his assistance in laboratory. 


\section{REFERENCES}

[1] Ahmed, K., Das, M., Islam, M. M., Akter, M. S., Islam, S., \& AlMansur, M. A. (2011). Physico-chemical properties of tannery and textile effluents and surface water of River Buriganga and Karnatoli, Bangladesh. World Applied Sciences Journal, 12(2), 152-159.

[2] Bakre, P. P., \& Sharma, A. (1995). Lead concentrations in House Sparrow (Passer domesticus) collected from urban area of Jaipur. Journal of Environmental Biology, 16(1), 15-17.

[3] Blanco-Penedo, I., Cruz, J. M., López-Alonso, M., Miranda, M., Castillo, C., Hernández, J., \&Benedito, J. L. (2006). Influence of copper status on the accumulation of toxic and essential metals in cattle. Environment International, 32(7), 901-906.

[4] Barceloux DG (1999). Zinc. J ToxicolClinToxicol, 37,279-292

[5] Begum, A., \&Sehrin, S. (2013). Levels of heavy metals in different tissues of pigeon (Columba livia) of Bangladesh for Safety Assessment for Human Consumption. Bangladesh Pharmaceutical Journal, 16(1), 81-87.

[6] Beyer, W. N., Spann, J. W., Sileo, L., \&Franson, J. C. (1988). Lead poisoning in six captive avian species. Archives of Environmental Contamination and Toxicology, 17(1), 121-130.

[7] Bhuyan, M. S., \& Islam, M. S. (2017). A critical review of heavy metal pollution and its effects in Bangladesh. Science Journal of Energy Engineering, 5, 95-108.

[8] Blakely, J. K., Neher, D. A., \&Spongberg, A. L. (2002). Soil invertebrate and microbial communities and decomposition as indicators of polycyclic aromatic hydrocarbon contamination. Applied Soil Ecology, 21(1), 71-88.

[9] Burger, J., \&Gochfeld, M. (1996). Heavy metal and selenium levels in Franklin's gull (Laruspipixcan) parents and their eggs. Archives of Environmental Contamination and Toxicology, 30(4), 487-491.

[10] Clark, A. J., \&Scheuhammer, A. M. (2003). Lead poisoning in upland-foraging birds of prey in Canada. Ecotoxicology, 12(1-4), 2330.

[11] Eeva, T., \&Lehikoinen, E. (1996). Growth and mortality of nestling great tits (Parus major) and pied flycatchers (Ficedulahypoleuca) in a heavy metal pollution gradient. Oecologia, 108(4), 631-639.

[12] Eeva, T., Ahola, M., \&Lehikoinen, E. (2009). Breeding performance of blue tits (Cyanistescaeruleus) and great tits (Parus major) in a heavy metal polluted area. Environmental Pollution, 157(11), 31263131.

[13] Frank, A., \& Borg, K. (1979). Heavy metals in the tissues of the Mute Swan (Cygnus olor). Acta Vet Scand, 20, 447-465.

[14] Franson, J. C., Lahner, L. L., Meteyer, C. U., \&Rattner, B. A. (2012). Copper pellets simulating oral exposure to copper ammunition: absence of toxicity in American kestrels (Falco sparverius). Archives of environmental contamination and toxicology, 62(1), 145-153.

[15] Furness. R. W. (1996). Cadmium in birds.In: W. N. Beyer, G.H. Heinz, \& A.W. Redmon-Norwood Environmental Contaminants in Wildlife - Interpreting tissue concentrations. ( ${ }^{\text {th }}$ ed., Pp 389-404). (Ed.), Bpca Raton, Florida: Lewis Publishers, CRC press.

[16] Gochfeld, J. B. M. (2000). Effects of lead on birds (Laridae): a review of laboratory and field studies. Journal of Toxicology and Environmental Health Part B: Critical Reviews, 3(2), 59-78.

[17] Gupta, V. (2013). Mammalian feces as bio-indicator of heavy metal contamination in Bikaner Zoological Garden, Rajasthan, India. Res. J. Animal, Veterinary and Fishery Sci, 1(5), 10-15.

[18] Jayakumar, R., \&Muralidharan, S. (2011). Metal contamination in select species of birds in Nilgiris District, Tamil Nadu, India. Bulletin of environmental contamination and toxicology, 87(2), 166-170.

[19] Kim, J., \& Koo, T. H. (2010). Acute and/or chronic contaminations of heavy metals in shorebirds from Korea. Journal of environmental monitoring, 12(8), 1613-1618.
[20] Krejpcio, Z., \&Trojanowska, E. (2000). The effect of lead (II) and cadmium (II) ions on pepsin and trypsin activity in vitro. Bromatologia I ChemiaToksykologiczna, 33(1), 43-48.

[21] Lewis, L. A., Poppenga, R. J., Davidson, W. R., Fischer, J. R., \& Morgan, K. A. (2001). Lead toxicosis and trace element levels in wild birds and mammals at a firearms training facility. Archives of Environmental Contamination and Toxicology, 41(2), 208-214.

[22] Mochizuki, M., Hondo, R., Kumon, K., Sasaki, R., Matsuba, H., \& Ueda, F. (2002). Cadmium contamination in wild birds as an indicator of environmental pollution. Environmental Monitoring and Assessment, 73(3), 229-235.

[23] Mohanta, M. K., Salam, M. A., Saha, A. K., Hasan, A., \& Roy, A. K. (2010). Effects of tannery effluents on survival and histopathological changes in different organs of Channa punctatus. Asian J. Exp. Biol. Sci, 1(2), 294-302.

[24] Muralidharan S. (1995). Heavy metal contamination in and around the aquatic environs of Keoladeo National Park, Bharatpur. Thesis submitted to University of Rajasthan

[25] Pandey, G., \& Madhuri, S. (2014). Heavy metals causing toxicity in animals and fishes. Research Journal of Animal, Veterinary and Fishery Sciences, 2(2), 17-23.

[26] Pechova, A., \& Pavlata, L. (2007).Chromium as an essential nutrient: a review. VeterinarniMedicina-Praha, 52(1), 1.

[27] Rajamani, J., \& Subramanian, M. (2015). Toxicity assessment on the levels of select metals in the Critically Endangered Indian Whitebacked Vulture, Gyps bengalensis, in India. Bulletin of environmental contamination and toxicology, 94(6), 722-726.

[28] Riggs, S. M., Puschner, B., \& Tell, L. A. (2002). Management of an ingested lead foreign body in an Amazon parrot. Veterinary and human toxicology, 44(6), 345-348.

[29] Scheuhammer, A. M. (1987). The chronic toxicity of aluminium, cadmium, mercury, and lead in birds: a review. Environmental Pollution, 46(4), 263-295.

[30] Status and conservation of herons. (2000). Herons as indicators. (Academic Press), New York: Erwin RM,Custer TW.

[31] Straw Jr, J. A., Kbementz, D. G., \&Ounde, M. W. (2000). Determinants of lead shot, rice, and grit ingestion in ducks and coots. Journal of Wildlife Management, 64(4), 939-947.

[32] Szymczyk, K., \&Zalewski, K. (2003). Copper, Zinc, Lead and Cadmium Content in Liver and Muscles of Mallards (AnasPlatyrhychnos) and Other Hunting Fowl Species in Warmia and Mazury in 1999-2000. Polish Journal of Environmental Studies, 12(3).

[33] Torres, J., Foronda, P., Eira, C., Miquel, J., \&Feliu, C. (2010). Trace element concentrations in Raillietinamicracantha in comparison to its definitive host, the feral pigeon Columba livia in Santa Cruz de Tenerife (Canary Archipelago, Spain). Archives of environmental contamination and toxicology, 58(1), 176-182.

[34] Tsipoura, N., Burger, J., Newhouse, M., Jeitner, C., Gochfeld, M., \& Mizrahi, D. (2011). Lead, mercury, cadmium, chromium, and arsenic levels in eggs, feathers, and tissues of Canada geese of the New Jersey Meadowlands. Environmental research, 111(6), 775-784.

[35] US Fish \& Wildlife Service. (1988). Lead hazards to fish, wildlife, and invertebrates: A synoptic review. (Biological Report). Washington, DC, USA: R. Eisler.

[36] US Fish and Wildlife Service. (1986). Chromium hazards to fish, wildlife, and invertebrates: a synoptic review. (Biological Report). Washington, USA: R. Eisler.

[37] Wilson, I. D. (1937). An early report of lead poisoning in waterfowl Science. (New Series), 86(2236), 423.

[38] World Health Organization. (1992). Cadmium. Environmental Health Criteria. (World Health Organisation, International Programme on Chemical Safety). Geneva, Switzerland.

[39] Jin, S. D., Seo, S. G., Shin, Y. U., Bing, K. C., Kang, T. H., Paek, W. K., \& Lee, D. P. (2012). Heavy metal accumulations of 4 species of Anseriformes in Korea. Journal of Korean Nature, 5(4), 345-349. 